\title{
Religion and/or A business? A critical reading of Tree without Roots and $P K$
}

\author{
Md. Al Walid* and Robiul Islam \\ Department of English, Jessore University of Science and Technology, Jessore 7408, Bangladesh \\ *Author for correspondence; \\ E-mail: md.alwalid.eng @just.edu.bd
}

\begin{abstract}
Religion, with intent, has been misinterpreted by a number of ersatz-saints for their earthly sakes. The paper critically gives a substantial reading of a select South Asian film and a novel with a view to reforming pseudo- religious practices for earthly gain and fanaticism of society, especially, in Bangladesh and India. Showing pseudo-religious activities as a worldly concerned issue from past to present analyzing in the light of Tree without Roots by Niaz Zaman (a translated form of Lal Shalu by Syed Waliullah) and PK- a film by Rajkumar Hirani, the paper argues that 'pseudo-religious operation' creates inconsistency among religious ideologies and deviates people from religious ideology to religious superstition, and mostly pseudo-saints use it as a business resource. This research is done with the content analysis of text and film applying qualitative research approach. The argument is developed through different and differing conceptualization of religion and pseudo-religion. Subsequently, it discusses 'operation of pseudo-religion' in Tree Without Roots and in PK. Finally it aims to demonstrate how pseudo-religion differs from concept of religion, whether it is antireligious ideology and how it creates bewilderment.
\end{abstract}

Keywords - Idea of religion, pseudo-religion, ersatz-saints, pseudo-religious operation, business etc.

\section{INTRODUCTION}

The paper substantially shows how the concept of pseudo-religion taints religion and religious ideologies, how it controls the people of a society and intensifies the blind belief of people about religion, how it deviates people from religious path to pseudo-religious path, how it impacts on religious ideologies, how and why pseudoreligious practices have been possible for lack of education or unsighted over belief on religion or in the name of God and religion; hence most of the pseudosaints use religion for their own purposes, how pseudosaints use religion for gaining their worldly success, how they make people fool in the name of God and religion, and how they use religion in their own ways. Thus, it attempts to find out the impact of pseudo-religion on society, religious ideologies, common people, pious www.ijels.com persons and fanaticism of society with the references of Tree Without Roots, a novel by Niaz Zaman (translated form of Lal Shalu by Syed Waliullah) and PK, a Bollywood Hindi film by Rajkumar Hirani.

\section{METHODOLOGY}

This paper is mainly a qualitative research. It aims to analyze the content of the select novel and film. This method allows us for varied scope of critical interpretation and discussion. It also allows us for the establishment of original suggestions with a critical insight into pseudo-ideologies, pseudo-saints and fanaticism in society. Taking much from manifold online resources, this paper is also a comprehensive form of library research. The discussion will be followed by the origin and discussion of pseudo-religious ideologies in the light of content analysis. The film $\boldsymbol{P K}$ and the novel Tree Without Roots are taken as primary sources of this research. In this regard, an elaborate analysis of the major characters and the content analysis of incidents of the film and text have been done.

Clarification of 'pseudo-religious ideology': To clarify 'pseudo-religious ideology', at first, the meaning of 'religion' has been offered. It is followed by meaning of 'pseudo-religion.'

As Shaykh Mansour Leghaei says,

The divine message of the messengers of God is called 'Religion'. The term 'religion' (Deen in Arabic) literally means obedience and following the path and the command of God. Religion is the collection of divine laws which designs a system of life, the following of which brings man closer to God and a prosperous life both here and in the hereafter. (Islam the First and Last Religion, Online)

Ronjoy Sen, in his article "Defining Religion: The Indian Supreme Court and Hinduism" offered,

Hinduism can be read as a "mosaic of distinct cults, deities, sects and ideas and the adjusting, juxtaposing or distancing of these to existing ones, the placement drawing not only on belief 
and ideas but also on the socio-economic reality." (Online)

Emile Durkheim, the eminent social scientist opined, Religion is a unified system of beliefs and practices relative to sacred things which unite into on single moral community called a church, all those who adhere to them." This is a functional definition, focused on the moral unification function of religion. (Elementary Forms of Religious Life, p.44)

Karl Marx said, "Religion is the opiate of the masses." (faculty.Smem.edu/.../ Basic -Characteristics-religionPdf)

In this paper, Religion is treated as a set of beliefs which can control people with their consent.

The term pseudo-religion (from Gkpseudos",, lie, falsehood") and ersatz religion are used colloquiallyand unfortunately sometimes in scholarly writing-for to different social phenomena, without clear distinction (a construct for which their adherents claim a religious quality, while churches and critics dispute these claims (e.g. some of the so- called new religious movements); and (b) constructs such as sporting events, certain political events, concerts and shows to which a religion. (referenceworks.brillonline.co m/--/)

A pseudo-Christian religion is a group of people who follow a leader (group of leaders, organizations) who, while claiming to be Christians and teach true Christians doctrine, actually distorts and denies fundamental and distinctive doctrines of the Christian faith.(https://www.summit.org/---/discerning)

In this paper, pseudo-religion means man-made religious ideology that has been performed for worldly success by ersatz-saints. It is not a part of religion rather, it is an anti-religious ideology.

\section{Operation of 'ps eudo-religion'}

(a) 'Pseudo-religion' in Tree without Roots

Mazar (The word "Mazar" adopted from Tree

Without Roots translated by NiazZaman, p.16 that means "grave of a saint") plays a vital role for pseudo-religious activities. From time to time, Mazar has been used by fake-saints for their pseudo-religious purposes. They are trying to draw the attention of common uncritical people. Their target, chiefly, is to draw the attention of illiterate or semi- illiterate people.

They saw a stranger with a thin beard, standing in the middle of the road. His hands were raised, face turned up towards the sky, eyes closed. He was praying. Time passed but still he stood thus, oblivious of his surroundings and utterly motionless, as if the windless day had turned him into a statue. (Tree Without Roots, p.10).
Sometimes the prayers are done in the open place by pseudo-saints only for showing the people. It is prohibited in the eye of Islam to pray for mere show-off. Those people who pray for showing people will certainly go to Hell. "So, woe to the worshipers. Who are neglectful of their prayers, those who (want but) to be seen (of men)." (Al-Quran, sura: Maun, verse 4-6)

Pseudo- saints try to lead their followers according to their own created ideologies. They apply their own ideologies so that they can completely control their followers. In their pseudo-religious ideologies, they include the idea of supernatural God, mere worshipping to saints, immortal life of saints and greed for going to paradise. Mazar and saints are the medium of reaching to God are shown by pseudo-saints. To represent the respect of saints towards people, saints are alive told by their devotees after their deaths. As in the text,

After this outburst, the stranger again closed his eyes and prayed silently. But this silence was short-lived. His anger quickly returned. Glaring at the men in deep indignation, he continued, 'Yes the saint has been living amongst you unknown and uncared for, a saint who is alive even in death, a saint who has regard for you and who protects you. (Tree Without Roots, p.11)

The idea of Mazar comes to the mind of Majeed through conversation with a hunter. The protagonist, Majeed, comes to know a village and gets information of an old grave located in that village.

The unknown grave had become a mazar, the abode of a saint who lived on ever after death. 'You have earned God's gratitude,' said Majeed, his voice trembling with emotion.

(Tree Without Roots, p.16)

Shrewd Majeed let the villagers inform that this is not a simple grave. It is the Mazar of a great saint. He proves it as a matter of respect.

In the pseudo-religious activities, religion is used as a scheming weapon by pseudo-saints. By using the name of God, they bring fear in the mind of followers. Sometimes, they act as they always do the right one. On the other hand, their followers are always doing wrong activities. Majeed, the protagonist of the novel- Tree without Roots, shows his convincing power over common people. He tries to show their fault so that they will obey him and get rid of vices.

"You are all blind" he cried out accusingly. "You are ignorant men, men without understanding. If you are not, then how could you have left the grave _ no, it is not a mere grave but a Mazar_ how could you have left the Mazar of Saint Shah Sadeque unattended like this?" After this outburst, the stranger 
again closed his eyes and prayed silently. But this silence was short-lived. His anger quickly returned. Glaring at the men in deep indignation, he continued, 'Yes the saint has been living amongst you unknown and uncared for, a saint who is alive even in death, a saint who has regard for you and who protects you. And behold how you treat him. But he shows great mercy. For, if it were otherwise, would not your homes have turned to ashes for this unpardonable neglect? Would not your crops have been consumed in the fiercest drought, would not your children have died of pestilence? But this is a merciful spirit and his kindness knows no bounds."(Tree without Roots, p.11)

They try to act that they are the representatives of God on the earth. The conversation between Majeed and hunter represents that Majeed is the representative of God on the earth. He has taken the responsibility of all people.

When the muezzin spoke about his home, his eyes softened. His memories were bitter-sweet, but he controlled his tongue. The people here, he said, had been shut out from the light of God for many centuries. Perhaps God`s light had never shone on them until his arrival. They were illiterate, these infidels. Then he had seen them he had felt he had a duty to perform among them and so had stayed on (Tree Without roots, p.7)

Pseudo-saints show antagonistic attitude towards education. Education is compared with light. It removes the darkness of ignorance from society. The light of education assists a person to judge everything. A person can differentiate between right and wrong. Pseudoreligious activities are the dark side of religion. Pseudosaints feel fear of education. Education can open the eyes of people and directly open the real character. Pseudoreligious activities can be vivid with the light of education. So, pseudo-saints do not allow establishing educational institution.The conversation between Khaleque and Majeed represents Majeed's antagonistic attitude toward the establishment of educational institution. When Khaleque informs Majeed about Modabber Mian's youngest son's plan of establishing of a school in the village, he directly opposes it. Rather, he wants to establish a Maktab (Tree Without Roots.p 24) Majeed directly opposes for the establishment of school. It is his fear that he can lose his position. He wants to keep people in darkness. He wants to control over all the people by spreading his misinterpreted concept of religion.
Khaleque had founded a Maktab, and a flock of children now learned the first principles of the faith there. This had pleased Majeed greatly, and, in a subtle way, he now felt close to that life which circumstances had forced him to abandon....This is the way we used to learn religion and there is no better way. God name should be uttered with the first breath of one's life. (Tree Without Roots, p.24)

Majeed wants to input his ideologies on minds of people at the very beginning of their life because it enhances the process of control easily. He attempts to brain-wash people and convert them in his outlined paths. Majeed shows his antagonistic attitude towards the establishment of a school.

ক-দিন ধরে একটা কথা ভাসে। মোদাব্বের মিয়ার ছেলে আক্কাস নাকি গ্রামে একটা স্কুল বসাবে।...অতএব সন্ধ্যার পর বৈঠক ডাকা হলো। আক্কাস এল, আক্কাসের বাপ মোদাব্বের এল। আসল কথা শুরুর আগে মজিদ আক্কাস কে কতখন চেয়ে চেয়ে দেখল।...ঠাস করে চড় মারার ভঙ্গিতে সে প্রশ্ন করল- তোমার দাড়ি কই, মিয়া? (লালসালু, পেজ ৫৫)

The extract means that there floats a word for few days. Moddaber's son Akkas will establish a school in the village. Therefore, after evening, meeting has been called off. Akkas and Akkas' father, Moddaber have come. Before starting the main point, Majeed has looked forward to Akkas.... Out of his anger, he slaps Akkas and asks, "Where is your beard, Mian?" (Translation from Lal Shalu p.55 by Syed Waliullah)

With an irrelevant question, he tries to insult him. He shows his superiority to Akkas. Majeed proves that Akkas' establishment of school is nothing but a bad purpose.These saints, at first, target some people. Then they impose their ideologies, beliefs, thoughts and knowledge on them. They usually target illiterate or semiilliterate people. They deliver their produced speech. In their speech, they include the description of God and religion. They tell them what will happen in their postdeath life. They may face dreadful condition. They create fear in their minds. Sometimes, they target the head of a family, society, community or village. They convince him so that, by the help of that person, they can easily keep their influence on them.

In the novel, Tree Without roots, we see, again and again, Majeed tries to make good relationship with Khaleque. Khaleque is his first target person. By using Khaleque as a weapon, he starts keeping influence on the others. 
Religion is used as an income source by pseudosaints. In, pseudo-religious activities, the name of God and Mazar are used as the income source by pseudosaints. They use religion as their business capital. It seems that they invest it (religion) on people. In return, people make him content. Only in business policy, we expect to get more return than the original. As Majeed Says:

They have plenty of food and much livestock. But they were not happy. For how can one be happy if one is shut off from the light of heaven? I remained among them to them the path of god. I gave them happiness and they made me happy in return. Yes, I was quite happy there. But then,' he added, after letting his glance pass over the entire assembly, 'one night I dreamed a dream. (Tree Without Roots, p.12)

By using religion as an investment, he gains worldly pleasures. He sells the religious materials as he considers religious anything as material. The verses of the holy Quran are more valuable than the worldly money. Money is a very trifling matter. "Part not revelations for trifling price" (A1-Quran, Sura: Al -Bukhara-verse 41) Pseudo-saints have contrary relationship amongs themselves. One pseudo-saint cannot tolerate another pseudo-saint. They think that their respects, their values and their wealth are going to be shared or lost. With the analysis of Majeed's character, we find fear of losing his position. So, he starts stopping the reputation of an old pir.

"The pir was an old man. It was said that he had once had fire in his eyes and thunder in his voice. (Tree Without Roots, p.49). Majeed was worried, and, he thought himself, he had good reason to be. True, he commanded respect and reverence as the guardian of saint's grave, now embellished with a red cloth, silver trimmings and a yellow canopy, but there were no miraculous tales about any extraordinary spiritual powers to his credit. He had turned the people towards God, strengthening their moral fibre by tireless preaching and when necessary, by taking severe action against backsliders. But he himself remained an ordinary mortal. All his power and glory came from the shrouded mystery of the Mazar. (Tree Without Roots, p.50)

(b) 'Ps eudo-religious operation' in $P K$
ISSN: 2456-7620

The use of the name of God and temple are very common phenomena in India. By using the name of god and temple, the pseudo-saints and Babas (according to $\boldsymbol{P K}$ "Baba" means the guide of Hindus, preacher of religious knowledge, founder of a temple and he gives all kinds of solutions to the people if common people fall in any problem) cheat with people. A TV reporter asks Baba that PK says this temple shouldn't be built because that jewel is his property. Tapaswi baba says in his TV interview, "When I chose this holy site... the birth place of Rama...sacred to lord Krishna... and wish to build a temple Why all these questions?"

These pseudo-saints or Babas, through brainwash, input their own manufactured ideologies on common people. Then common people think that they are dependent on the name of God, temple, worship and Baba's guidance.

PK is the story of an alien (Amir Khan) who lands in India according to cinematic representation of the film. PK learns about the concept of God through a common proverb used in India. The proved is "only God can help you". It is uttered by a policeman who refuses to help him find his remote control. He says, "The policemen are human, not Gods." He learns from the people that only he can solve your problems.

'God' is the only hope to get him "Remote Control" back. He visits temples, mosques, and churches. He tries to convince God of every religion and God of every faith. He pursues advices that are given by priests and religious leaders to convince the God of every religion. But Khan smartly points out some 'gurus' who use superstitions. They also start cheating with people. Jagat Janni, a TV reporter, plays a vital role as she simplifies PK's meeting with Baba and PK's public appearance on TV and with the common people, which popularizes his version of a logical approach towards God.

$\mathrm{He}$ starts raising questions about religious dogmas and traditions. His 'Remote Control' is a device without which he cannot go back to his planet. It is robbed by a stranger. He ships a journey to discover the world. He meets both good and bad people. He looks over places and acquires the language. At the time of his ordeals, he comes across different contexts and concepts. He eventually starts searching for 'God'. He starts distributing poster among the people. The poster contains 'Missing God'. 


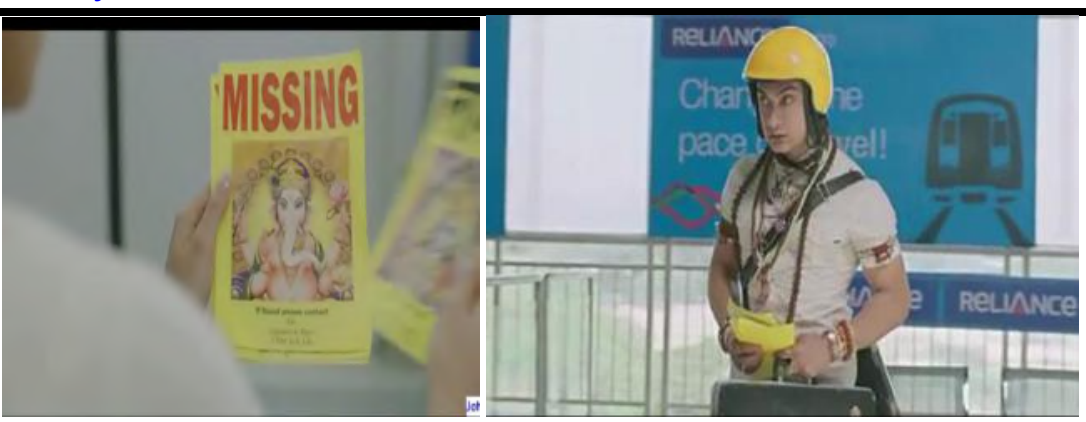

Fig.1: Screenshot from pk 2014

The name of God and religion has been used as a control-weapon by Tapaswi baba. The followers are bound to obey the 'baba' because they erroneously accepted the 'Babas' due to their ignorance. It seems that they even are ready to sacrifice their life for baba. Baba's controlling weapon acts accordingly what Baba wants. Baba convinces them with false speech and false god gifted device. Baba says:

I was in the snowcapped Himalayas... a light. A great infinite light...emanating from a small object on the ground. Looked at it, I closed my eyes in meditation. Suddenly, I felt a connection to God, enlighten me. What is this marvelous object...Which, even in the snows of winter gives me warmth? And God said, my, son. It is a jewel from Lord Shiva's broken pellet drum. Take it. Take it and build a shrine to venerate it. For, the mere sight of it. Will dispel the suffering of all loyal devotees. (pk,2014)

Tapaswi Baba (Saurabh Shukla) is followed by thousands of people including Jaggu's father (Parikshit sahni). He claims that Baba is capable to talk directly with
God. His prediction about Jaggu is that she will be jilted by her Muslim lover from Pakistan, Sharfaraz (Sushant sing Rajput), later is proved a misunderstanding.

Thousands of peoples' eyes are opened including Jaggu's father at the time of live show between PK and Baba. It is also proved that 'Remote Control' is not a God gifted device that helps Baba to be connected with God. Rather, it is the remote control device of PK. In the name of God or in the name of God gifted device, these Babas' bamboozle people. They merely try to convince people in the name of god or pseudo-religion.

PK (Amir Khan) shows the fanaticism of the followers. Jaggu's father is blind to Tapaswi baba. He places Baba in a position of reverence and calls him "Bhaagwan" means 'god'. Tapaswi Baba's photographs are found everywhere in his house. He keeps it for his blessing. He pastes them on walls, bathrooms, bed sheets and school bags. He cannot do any work without remembering baba. Baba gave him a "godbox". The "godbox" contains various Hindu Deities. A watch to some screenshots of PK can be given to make it much clear:

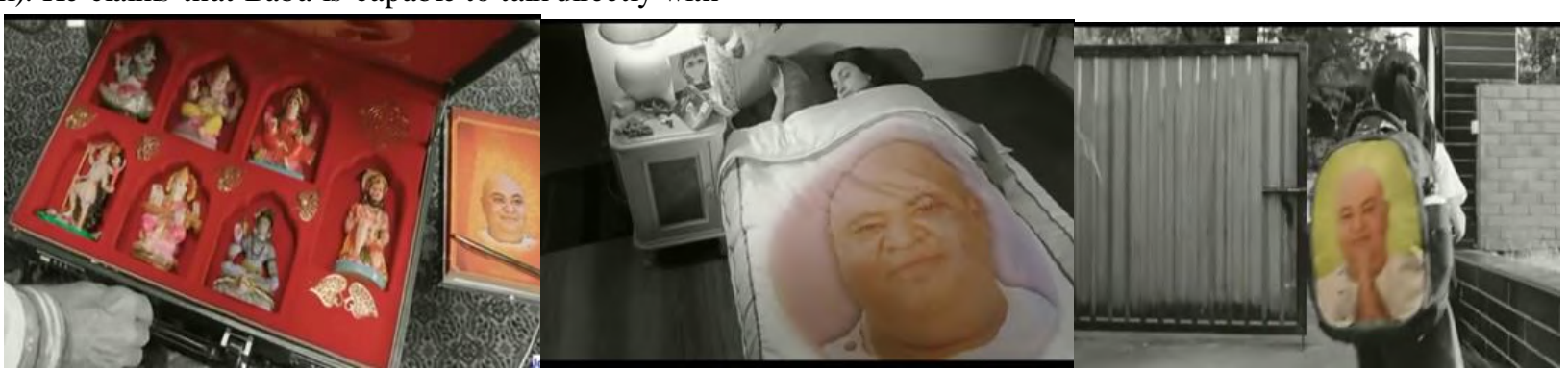

Fig.2: Screenshot and edited by me from pk 2014

Religion is used as a business capital by Tapaswi baba in the film $P K$. He starts running religious business. That is not recognized in religion. Some pseudo-religious representations are shown with the cinematic representation of the film $P K$.

Jaggu finds PK in a temple; he tries to steal money from charity 'Box'. For saving him from being beaten up, he pastes stickers of Hindu God on his face. It is his new idea to save him from that crime. When people see the picture of God on his face, they cannot slap him. They cannot slap on the picture of God. They cannot ignore it. The picture of God is used for his safety, to conceal his crime, to get the legality of his stealing business or earning. 


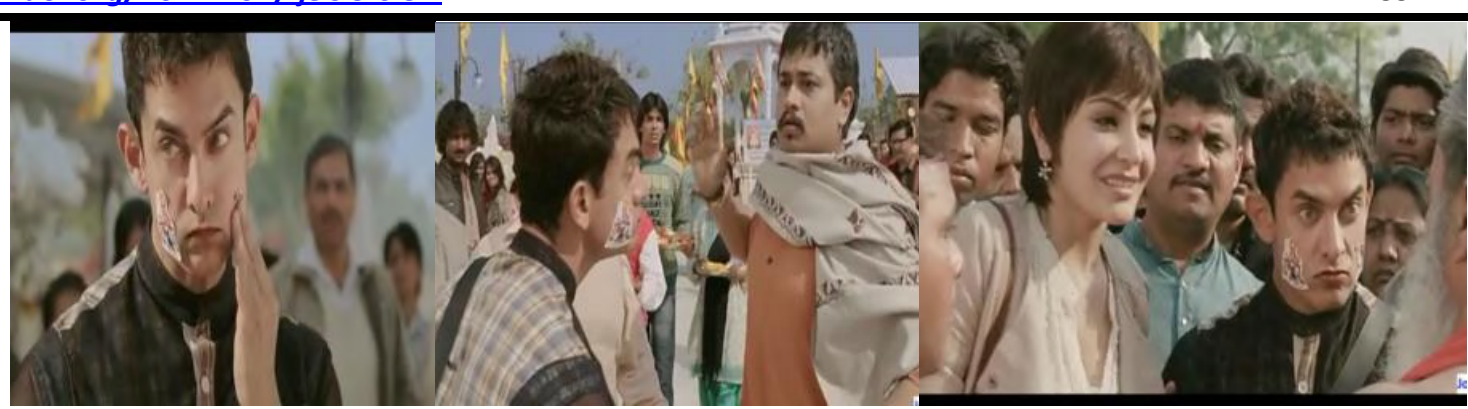

Fig.3: Screenshot and edited by me from pk 2014

We often experience a number of pseudo-saints in our society. They use religion and the name of God as poster as like in PK. In the name of God and religion, earning money for livelihood and luxury is their main concern. They lead the people to follow the wrong path.

PK does not believe in an idol of God. He raises questions, "Does God not listen directly?" PK's TV show asks people to expose fake saints from all religions. He says that ersatz-saints use fear of people for establishing their own business in the name of religion. They try to act that they are the representatives of God on the earth. To prove the idea, fake saints are doing their business in the name of God and religion. He tells Jaggu's father to stay with them. He places a stone on the earth and gives read color on its head. He also scatters some money beside it. He says that it is investment. According says:

This college is having exam. Students are all in a panic. Now we will star our fear business. I will show you. Here's the plant machinery. Initial investment. And now, the inauguration. Now, you will see... In 15 minutes invest will double." (PK, 2014)

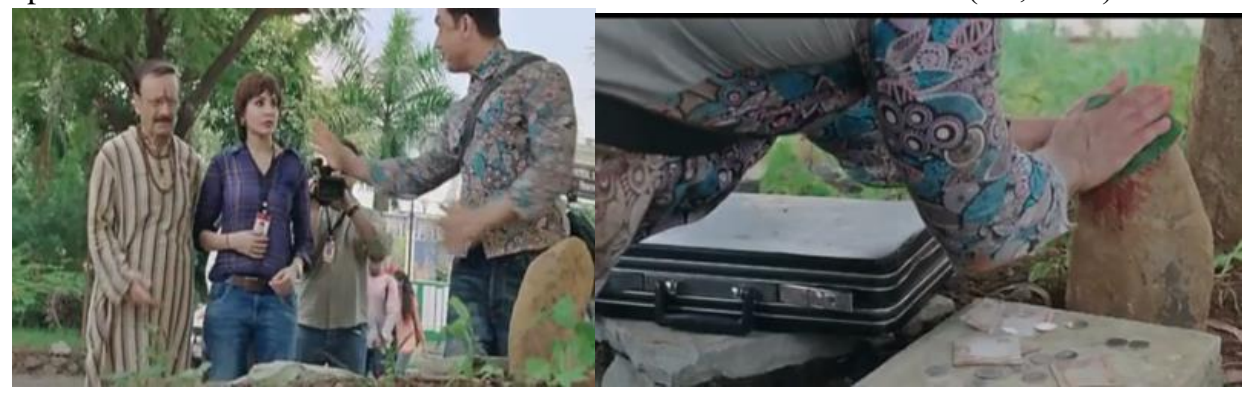

Fig.4: Screenshot and edited by me from pk 2014

In $P K$, when media represents baba positively, all people support baba. Baba's popularity increases dramatically. On the other hand, when media represents baba negatively, Baba's popularity has fallen from sky to earth. So, media's representation and media politics are greatly related to pseudo-religious activities

Pseudo-saints or Babas are conscious about their misdoing. They consciously do it for their respect, worldly pleasure and wealth. In PK, we have noticed that Tapas wi Baba is conscious about his misdoing. When PK attacks Baba with question, Baba indicates his volunteers to close the program.

\section{EVALUATION}

After the partition of India and Pakistan, the novel Lal Shalu was written by Syed Waliullah in 1948. It was translated in 1967 by Niaz Zaman. The people of Indian-subcontinent, in postcolonial period, would pass mysterious time. The arrival of many pirs (The word "pir" is taken from Tree Without Roots p.49) that means a religious figure or a preacher of a religion and saints in the geographical area of Indian subcontinent, for spreading religious knowledge is known to all. Some tricky pers ons have seized it as a chance and, in the name of religion; they stared gaining their worldly purposes. They started religious business. They grabbed religion as the way of their earnings. They started doing pseudoreligious activities. In the novel Tree without Roots, the translated form of Lal Shalu, We find Majeed as a religious figure. He came to Mahabbatpur, a fictional village, as a stranger. He claims that he is a pious person. He claims that he gets the information of mazar in his dream. He takes the responsibility of the people to lead them to the right path. In the name of God, religion, religious fear and Mazar, he gains worldly pleasure and wealth. With the presence of "superego" (Beginning theory,. p.93), Majeed has done all the pseudo-religious activities. He considers religion as his own property. $\mathrm{He}$ tries to impose his manufactured religious practices on the people according to his own ideologies, thoughts and beliefs. Subsequently, Religion is used as an investment. From this investment, he earns more and more worldly materials. 
$\boldsymbol{P K}$ is a 2014 Indian satirical comedy-drama film directed by Rajkumar Hirani. The full soundtrack released by Indian film association on 17 November 2014 (https://en.m.wikipedia.org>wiki>PK). India is a place where we find the existence of many religions and languages. The pseudo-religious activities of babas or saints are increasing day by day in India. $\boldsymbol{P K}$ is the commodious representation of pseudo-religious activities of 'babas'. In the film, we see that Tapaswi Baba is conscious about his pseudo-religious activities. He considers religion as his own property like Majeed, the protagonist of the novel Tree Without Roots. He enforces synthetic religious beliefs on the people according to his own wishes, thoughts and beliefs. He convinces people by narrating false story and showing God gifted device. He claims that he has the ability to be connected directly with God. He uses religion as an investment and, from this investment, he gains more and more profit.

\section{CONCLUSION}

The paper finally reaches at the decision that pseudo-religious activities are done by pseudo-saints or babas consciously and purposefully for gaining worldly pleasure, respect, value, wealth, controlling power and business opportunities. But the position of religion is higher than money, power, wealth and worldly pleasure. Religion is sacred from all kind guilt and blasphemy. It is considered as the touch stone of every religion and every faith. Pseudo-saints or Babas have been using religion for their own purposes. They are using religious ideologies for their betterment. They are leading people to follow wrong path. For these pseudo-saints or Babas and their pseudo-religious activities, the real value of religion is decreasing. People are diverting from religious beliefs to pseudo-religious beliefs. People are devoted to performing pseudo-religion instead of religion and religion is covered under pseudo-religion. To protect the real value of religion, religious beliefs and ideologies, pseudo-persons' activities should be stopped.

\section{REFERENCES}

[1] Al-Quran. http://www.Islamdharma.net.Web.18 July 2018.soft

[2] Barry, Peter.Beginning Theory.New Delhi11002.Vinod Vasishtha.2010.print.

[3] Bywater, Kevin and Summit Staff. "Discerning Pseudo-Christian Religion" Summit, Summit Ministries, $04 \quad$ September 2009, https://www.summit.org/---/discerning.oneline.28 July 2018

[4] Emile Durkheim, Elementary Forms of Religious Life.oneline.26 March 2018.

[5] Faculty.Smem.edu/.../ Basic -Characteristicsreligion-Pdf. Online. 30 june 2018.
[6] Fred, L. (2003). Organizational behavior. Beijing, Post \& Telecom Press.

[7] Hirani, Rajkumar. Pk, on 17 November 2014

[8] M. Leghaei, Shaykh. Islam the first and Last Religion. Online. https://www.alislam.org/articles/islam-first-and-last-religionshaykh-mansour-leghaei. Accessed: 07 July 2018.

[9] Sen, Ronjoy. "Defining Religion: The Indian Supreme Court and Hinduism” . Online. http://archiv.ub.uniheidelberg.de/volltextserver/6936/. Accessed: 11 July 2018

[10] Waliullah, Syed, Lal Shalu.38 banglabazer, Dhaka1100. Motherss publications. July 2014.print.

[11] William H. Swatos, Jr.Editor Hartford institute for Religious Research, Hartford Seminary.oneline.29 August 2018.

[12] referenceworks.brillonline.com/--/.web.27 may 2018

[13] Zhu, Y. X. (2002). Management psychology. Beijing: Higher Education Press

[14] Zaman, Niaz, Tree Without Roots (translated form of Lal shalu by Syed Waliullah).113 kazi Nazrul islam Avenue, Dhaka-1000,Bangladesh. Chatto and Windus.1967. Skylark. Print. 